\title{
SOUTH AFRICA AND THE SADC STAND-BY FORCE
}

\author{
Thomas Mandrup \\ Royal Danish Defence College
}

\section{Introduction}

Our country continues to provide hope on the continent, especially in the search for peace. We recall that during the two presentations to the United Nations Security Council for the deployment of a peacekeeping mission in Burundi, in 2002 and 2003, council members unanimously emphasised the importance that South Africa is playing in the continent. This view has been expressed in many other forums. (Zuma, 2003)

The regional powerhouse, South Africa, has since the introduction of the nonracial democratic dispensation in 1994, played a central and important role in the formation of both the regional and continental security architecture. With the establishment of the Southern African Development Community (SADC) in 1992, one of the central areas of collaboration for the community was envisioned to be security, understood within a broadened human security framework. Security was therefore from the outset one of the cornerstones of integration in the SADC. It was believed that the formation of a security community would help dismantle the enmities that had plagued regional relations during the apartheid era. For some parties, institutionalisation of relations pointed to a means of stabilising and disseminating a particular order. Such institutions depict the power relations prevailing at the time of their establishment, which, however, can change over time (Cox 1981:136). The integration ambition surrounding security correlated with the ambitions of South Africa, the new democratic government in the regional powerhouse. South Africa and its overall foreign policy ambitions desired the pursuit of peace, democracy and stability for economic growth and development in the region and within South Africa itself.

Since South Africa's acceptance into the SADC in 1994, the organisation has attempted to set up the required institutional framework to enable co-operation on security, both in terms of narrow military co-operation and regarding designated 
softer security issues, such as migration and cross-border crime. The military cooperation moved forward in the early years after 1994 with the 1996 decision of creating an Organ for Politics, Defence and Security Co-operation (OPDSC) ${ }^{1}$ and later the signing of the Mutual Defence Pact (MDP) in 2003, and eventually the creation of the Strategic Indicative Plan for the Organ (SIPO) in 2004, which operationalised the OPDSC (SADC 2004). However, the actual military cooperation, e.g. military exercises, came close to a standstill. Several developments obstructed military co-operation of which the evolving crisis in Zimbabwe and the subsequent withdrawal of donor support to, for instance, the Regional Peacekeeping Training Centre (RPTC) in Harare are but two examples. The RPTC constituted the backbone of the co-operation, but political differences between member states illustrated during the Zimbabwean crisis and following the mandate of the interventions in especially the DR Congo and partly Lesotho in 1998 all contributed to regional tensions. ${ }^{2}$

Despite the crisis, SADC members, and in particular South Africa, declared that the organisation would be able to form a regional stand-by brigade for the use of the African Union (AU) as part of its wider security architecture. On 17 August 2007, the SADC declared its stand-by-force operational at a large parade in Lusaka, Zambia and at the same occasion signed a memorandum of understanding on the SADCBRIG (SADC 2007). According to the timeline provided by the AU, the brigade should be fully operational by June 2010. Former South African deputy foreign minister Aziz Pahad stated after the launch that this was an important step, but that now there was much to be done securing joint levels and types of training, interoperability, etc. (Pahad 2007).

The question that continues to linger is to what extent this brigade is operational and for what purpose. Is this new regional military formation in its present form just a paper tiger, or is it "real progress" and an example of "successful" regional cooperation and integration? This article scrutinises the security co-operation and integration in SADC and asks whether an apparent lack of common values between SADC member states are blocking the security integration process, the creation of a security community, and thereby the establishment of an effective stand-by brigade, the so-called SADCBRIG. The article furthermore attempts to scrutinise the role played by South Africa in establishing the SADCBRIG.

1 The "C" has been added later after the SADC members agreed on the judicial framework for the OPDSC and its operationalisation in 2001.

2 There exists a vast literature covering the political crisis in SADC following the two interventions, see for instance Mandrup 2007a; Hammerstad 2003. 


\section{Security co-operation in Africa: Security on the continental and at sub-regional levels}

The members of the now defunct continental Organisation of African Unity (OAU) through their 1993 Cairo decision expressed the ambition that the OAU, and therefore also from 2002 the AU, should be able to deal effectively with the mounting challenge of conflict and destabilisation that afflicts the continent. The initiatives taken by the AU to handle security challenges on the continent was not new, but rather a renewed attempt to take responsibility for Africa's problems. However, it was only after the establishment of the AU in 2002 that the needed institutional reforms were initiated, attempting to bring to life these ambitions by the establishment of the relevant African Security Architecture. Based on a subsidiary principle, the AU's five economic regions were each given the responsibility of setting up a stand-by brigade for the use of the AU. ${ }^{3}$ (See Map below) ${ }^{4}$

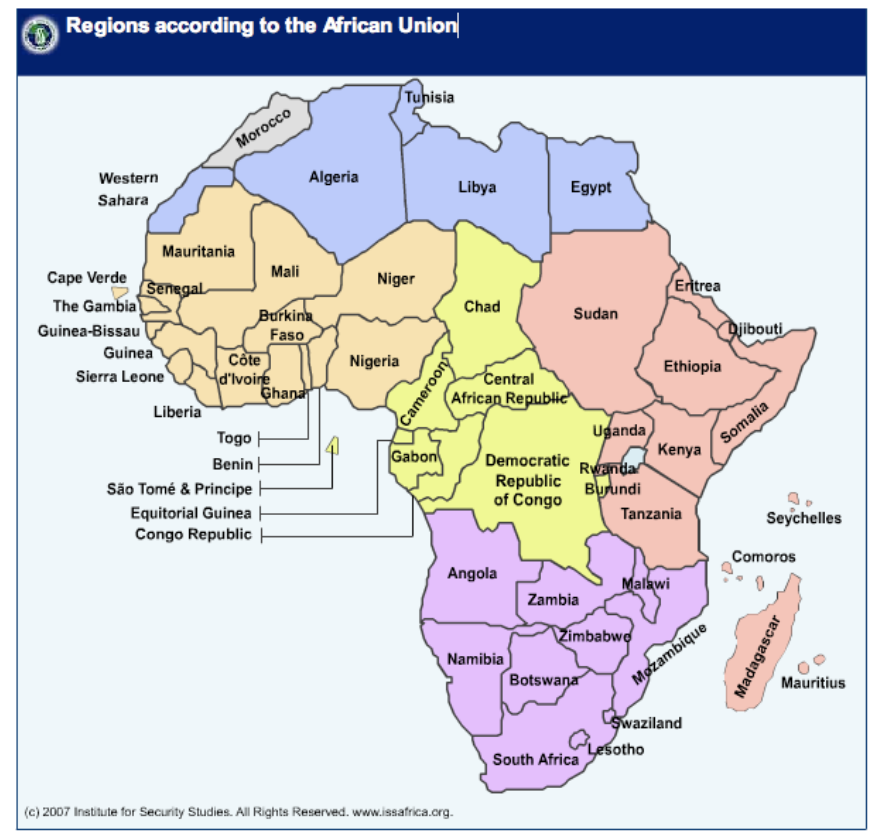

${ }^{3}$ For further reading on the African security architecture see for instance Mandrup and Moeller, The African Union: A Common Security Structure in the making? in Thruelsen (ed.). 2009. International Organisations: Their Role in Conflict Management.

${ }^{4}$ Map of African regions used with permission of the Institute for Security Studies, South Africa. 
The SADC was given the responsibility of setting up a brigade for the Southern African region. The AU's acceptance of the regional structures at face value has several inherent weaknesses, chiefly that the five regions do not correlate with the existing regional organisations to be found on the continent. In relation to the SADC, this means that, for instance, Tanzania, Madagascar and the Indian Ocean Islands, and the DR Congo (DRC) all take part in setting up the SADCBRIG, but in reality also belong to other regions. This is problematic in the sense that the situation creates uncertainty about who contributes to what regional brigade. In East Africa, the other members seem rather certain that, for instance, Tanzania will join EASBrig, despite its involvement in SADCBRIG and statements to the opposite. Another problem with the AU regional model is that three of the stand-by brigades, South, Central and West Africa, are tied to a regional organisation, while this is not the case in East and North Africa. The result is that stand-by brigades are formed outside a regional framework, creating uncertainty of the nature and capacity of these institutions.

\section{Security co-operation in SADC: Some reflections on the nature of the co- operation}

Already in 1992, the SADC signed the SADC Treaty, which stipulated that the organisation should include co-operation on security. In the treaty it was stated that SADC should:

... promote common political values, systems and other shared values, which are transmitted through institutions that are democratic, legitimate and effective; consolidate, defend and maintain democracy, peace, security and stability (SADC 1992 Article 5, 1. a-c).

Security-co-operation was therefore explicitly included in the treaty from the beginning as one of the building blocks of future regional co-operation. In 1996, the SADC decided to establish the OPDSC ${ }^{5}$, taking over from the old Front-Line State

\footnotetext{
${ }^{5}$ The Organ is responsible for promoting peace and security in the region. It reports to the SADC Summit and is headed by a Troika, consisting of a chairperson, incoming chairperson and outgoing chairperson. The SADC Summit Troika and the Organ Troika are mutually exclusive. A ministerial committee comprising of the ministers responsible for foreign affairs, defence, public security and state security from each of the member states reports to the chairperson and is responsible for the co-ordination of the work of the Organ and its structures. Ministers of Foreign Affairs of each member state perform the functions of the Organ relating to politics and diplomacy within the Inter-state Politics and Diplomacy Committee. Ministers
} 
(FLS) arrangement, which had lost its rationale with the end of apartheid. ${ }^{6}$ However, the Organ did not become operational until after the Blantyre Summit in August 2001 (SADC 2001). The five years in between showed the SADC that ambitions stated in the Treaty were difficult to institutionalise effectively, because, among other things, due to differences in opinion on the direction and ambitions for the SADC community's future development.

Several SADC member states have been and continue to be plagued by insecurity, underdevelopment, political tension and conflict, and there seems to have been a split in the organisation concerning its direction for future development. The objectives stated in the Treaty and the creation of the OPDSC all tend to point towards the creation of a security community. In contrast, however, the signing of the Mutual Defence Pact (MDP), the continued instability in the DRC and the handling of the political crises in, for instance, Swaziland and Zimbabwe, indicate to some extent that SADC is not going to transform itself into a security community, but that it will remain a looser association of states. As Nathan (2006) argues, it is difficult for states to integrate and develop into a community, when several of the members are still plagued by internal strife and instability. The problem of course being that integration and the sense of community are based on trust, which is difficult to establish if you fear the instability and values of your neighbour. This has turned out to have severe negative consequences for the military co-operation in the organisation. $^{7}$

In 1992, when the SADC treaty was signed in Windhoek, a section concerning future security co-operation within the SADC was included. The declaration stated that there was a need for:

... a framework of co-operation, which provides for ... strengthening regional solidarity, peace and security, in order for the people of the region to live and work together in peace and harmony ... The region

for Defence, Public Security and State Security work through the Inter-state Defence and Security Committee (ISS 2009).

6 The FLS alliance, consisting of Botswana, Tanzania, Zambia, Angola, Mozambique, Zimbabwe (1980) and Namibia (1990), was established in 1975, and focused on the decolonisation process in southern Africa, at a time when white minority regimes were in control in both Rhodesia and South Africa. The primary purpose of the creation of the FLS was to fight apartheid, and the formation of the alliance in 1975 was a consequence of South Africa's weakened regional hegemonic position after the failure of President Vorster's détente policies and the removal of the Portuguese "cordon sanitare" that had protected South Africa.

${ }^{7}$ For further reading on the nature of SADC co-operation, whether it is a community etc. See for instance Ngoma 2005; Nathan 2006; Hammerstad 2003; Vale 2003. 
needs, therefore, to establish a framework and mechanisms to strengthen regional solidarity, and provide for mutual peace and security (SADC 1992).

The signing of the declaration and the provisions stipulated in it expressed the new wave of hope and co-operation that spread like concentric rings throughout the African continent following the end of the Cold War in 1989-90 and the collapse of the apartheid regime in South Africa in the early 1990s. Hope was expressed that the African states could help each other in securing a stable future focused on developmental issues. A strong partnership between the southern African states would make it possible to create a foundation for a renaissance in the southern Africa sub-region, as well as Africa as a whole. At the time, South African Deputy President Thabo Mbeki called this the beginning of an African Renaissance, by means of which the continent would be enabled to blossom. The political leadership realised, however, that this could not be done without the creation of a stable political environment. It was therefore necessary to create a structure for security cooperation that might be able to provide stability, and at the same time respond swiftly to any evolving crisis. There could be no renaissance without peace and stability, and consequently there was a need for a strong regional collective security system able to handle the full spectrum of conflict, including a credible military capability.

The establishment of the SADCBRIG can, in some way, be seen as the culmination of the development of a security dimension in the SADC community. The SADC treaty of 1992 stipulates that security must be one of five pillars and integral to the areas for future co-operation between the SADC members. However, co-operation on security can take on many forms, and the history of the organisation since 1992 shows that it has been difficult for members to agree on security cooperation. Co-operation on security between states with divergent attitudes on issues such as human rights, democracy has proved to be problematic. It was particularly difficult to find a common platform upon which to anchor the desired co-operation. The South African leadership recognised the potential problems at an early stage in the process. Former Deputy Foreign Minister Aziz Pahad argued in 1996 in relation to the tension between South Africa's overarching foreign policy ambitions and the realities in South-South co-operation "There must be a possible [sic] contradiction between South-South co-operation and the values which we may want to protect. There has to be interaction between theory and practice". (Mills 1997:1). This statement by Pahad illustrates what has since then turned out to be a major predicament in South African foreign policy, i.e. creating consistency between theory and practice. In the area of security this has been particularly visible, because 
South Africa is an arena of relative peace, democracy and stability in an African security landscape plagued by war, conflict and undemocratic governments.

The interaction between theory and practice has been hotly debated in academic circles, and has been visible in the academic debate over SADC co-operation and integration and - of relevance to the topic of this article - co-operation in terms of security in particular. The SADC argues in its charter that the ambition is to create a "community". However, as argued by Nathan (2006: 2004), the very notion that the SADC is a community is questionable. The SADC region has never been characterised by close social relations and contacts between its member states. To be a community, there needs to be a common sense of belonging, that is, common values, goals, objectives etc. ${ }^{8}$ SADC co-operation is still understood as an association, with disagreements continually being solved by the use of force or by threats. According to Vale (2003:121), formal agreements still direct co-operation as exemplified by the MDP while individual members of SADC continue to prioritise national interests over collective ones. The SADC is, according to Vale (2003:123), not a community, but merely a Westphalian system structured around "South Africa - the first in a community of unequal's". He also argues that:

The failure to recognize that the SADC was less than it pretended to be eventually corroded the media hype and propaganda that were frantically being used to build its image - and South Africa's averred pivotal role in it (Vale 2003:122).

Swatuk (2003:8), in support of this view, argues that high politics in the SADC continue to be the "province of military power, diplomacy and statecraft". It is of course true that, despite the 2001 reform process, only limited progress has been detected in several sections of the SADC's co-operation. However, progress has been made and especially the introduction of several reform proposals and common value documents, common standards for electoral reform, show that at least the institutional frameworks are being created and thus fulfilling elements of the longterm objective of creating common standards and values in a community. However, it is important to keep in mind that concept and idea behind security communities have never been confined to the governmental level and include a sense of community that encompasses a "we feeling". This is generally characterised by mutual sympathy, consideration, loyalties, trust and responsiveness in decision-

\footnotetext{
${ }^{8}$ This is not a rejection of the existence of ideas and values such as pan-Africanism and Ubuntu cutting across boundaries. However, as Lodge (2003) rightly points out, these principles often do not represent more than mere political rhetoric that is used to sell another political message and objective. The use of the term 'renaissance' may be another example of this (Lodge 2003).
} 
making (Nathan 2006:276), a trust that, according to Vale (2003:121) and Swatuk (2003:8), cannot be found in the SADC. The recent attempts of creating a SADCBRIG support this claim. One of the problems for SADC members in this regard is the internal instability in several of the member states, which makes it difficult to create trust amongst and in between member states. A security community cannot simply be understood as the absence of war, nor even of the likelihood of war between states, but must also be seen as the likelihood of instability within states (Nathan 2006:277).

Several member states continue to be affected by instability and civil strife, and the SADC also suffers because the expectation of a continued absence of violence and peaceful change is missing. ${ }^{9}$ Intrastate conflicts and unrest will continue to destabilise the region, and thus jeopardise the potential for a security community to exist. However, when dealing with Southern Africa, the importance of the common anti-colonial and anti-apartheid history should not be underestimated, and this constitutes the common sense of belonging in the SADC, that Nathan, Vale and Swatuk claim do not exist, but which researchers like Ngoma (2005) argues is central to understanding the nature of the SADC cohesion. It is therefore also interesting to see that the South African government in August 2008 argued that its three main priorities for its SADC chairmanship were deepening regional economic integration, intensifying regional infrastructure development, and restoring and strengthening political unity and cohesion (Zuma 2008). These three priorities indicate that the South African government has recognised the lack of common values.

\section{The role and nature of the African Stand-by Force (ASF): Defence against aggression or peace support operations?}

In a speech before the participants of the first expert meeting on the establishment of a Common African Defence and Security Policy in Johannesburg, the then South African Foreign Minister, Dlamini-Zuma, concluded that, since the end of the Cold War had not provided the peace and stability that had been hoped for, it was time for a common African Defence and Security policy to be drawn up (Zuma 2003). The aim of the policy was to create a new framework that was binding on all AU members, forcing them to bring their domestic policies in line with the new AU policies. Zuma argues that the drafters needed to go beyond a narrow definition of security by using positive experiences and ignoring negative ones in

${ }^{9}$ In 2009, instability, political and/or military, continued or flared up in places like the DR Congo (DRC), Zimbabwe, Swaziland, Madagascar and Lesotho. In September 2009, the DRC even assumed the chairmanship of the SADC, while the eastern part of the country continues to be in conflict. 
drawing up a model document. The ambition was also to breathe new life into Kwame Nkrumah's old idea of creating a common African defence and security policy. Collective security and defence treaties will, at the margins, remove the perception of threat. However, the nature of this kind of treaty is often determined by the power structure within a particular region, which means that when the distribution of power between actors changes, the nature of the alliance will change as well. Acting against this is the level of the integration and the mere size of the alliance.

The strengthened South African position in the SADC, and in Africa in general, has speeded up the regional integration process. South Africa is providing public goods to its region, in relation to direct economic investments, but also in liberalising trade in Africa and attempting to deliver security through negotiations and actual military deployment. South Africa's power in the system is exercised through rules and institutions, and ultimately the weaker partners in the system are given informal access to the process of policy formation in both regional and continental organisations (Ikenberry 2004:2). South Africa is therefore creating a new consensual system, dominated by itself, and basically sustained by its economic and, to some extent, military capacity, at least at the sub-regional level and to a lesser extent at the continental level. The states in the SADC seek to co-operate and manage their disputes and avoid war by seeking to silence the security dilemma through both their own actions and their assumptions about the behaviour of others (Jervis 1985:78; Jervis 1982:364).

The SADC treaty of 1992 is an example of confidence-building measures, in which the respective states expressed the goal of creating formal institutional frameworks for future co-operation in the area of security. These initiatives were based on the informal FLS structure, which had co-ordinated the struggles of South Africa's neighbours against the apartheid state. In the case of SADC and even the $\mathrm{AU}$, it could be argued that the signing of the MDP and the Constitutive Act of the $\mathrm{AU}$, apart from being formal agreements transferring some national sovereignty, both function as threat-reducing measures in inter-state relations and as building blocks in the creation of a new security structure in Africa. In the South African Department of Foreign Affairs (DFA), this process of creating confidence-building measures was described as an "open-door closed-door strategy", that is, one of replacing "bad habits" with new and better ones (Short \& Castleman 2003). By getting its African partners to sign the new agreements, the South African government is hoping that they will also be compelled to follow the very same agreements and principles over time. 
The new African Defence and Security Policy expresses the aim of being able to fend off perceived external threats to the security of the AU members, including preventing war among themselves. This basic principle was stressed by former Mozambican President Joaquim Chissano, when, in his capacity as chairman of the AU, he stated concerning the ASF (African Standby Force) that:

From a strategic point of view, the African Standby Force represents a dissuading factor against threats to the sovereignty and territorial integrity of our states. It would be an instrument for intervention (Chissano 2004).

The wording is interesting, because Chissano focused on the issues of sovereignty and territorial integrity when addressing the question of the ASF, very much in line with the principles outlined in the SADC MDP. Furthermore, the description "a dissuading" factor is also interesting because it does not say who is being dissuaded. Was this a message to the warring parties in the DRC, primarily Uganda and Rwanda, or was it focused outside Africa as a deterrence to outside aggression against Sudan? As former Foreign Minister Dlamini-Zuma argued, this whole notion is based on the idea of the ASF as a collective defence structure rather than as a means of collective security. This was underlined by the signing of the AU Non-Aggression and Common Defence Pact in January 2005, which focused on common defence, not collective security. This pact states that an attack on one member is to be considered an attack on all, and that the signatories are obliged to respond with all available means (AU 2005a Article 1 c i ; Article 4b).

The South African scholar Peter Vale (2003:36) argued in his book on regional security dynamics in Southern Africa, that in the colonial states in southern Africa, the crucial issue was not the security of the general population in the territories, but protection of the in-migrating minority against the native majority. Since independence, this has continued in different forms, but the basic principle continues to be the same, namely security is concerned with protecting some sections of these states' societies against other sections. This touches on the two basic interpretations of the nature of the ASF, namely that it is either a tool for the current African elite for safeguarding their powerbase, or that the ASF is the claimed tool of being able to prevent and stop future Rwandan-type genocides, which was also recently noted by Baker and Maeresera (2009).

The truth should probably be found somewhere in between, which, for instance, has been visible in the different interpretations of the mandate, organisation and composition of the ASF in the different regions. In the case of EASBRIG, there is no existing regional organisation that includes all members of the eastern region - a matter complicating the setting up of the brigade. EASBRIG members expect that 
the brigade is to be used inside its own region, for instance in Somalia. It could therefore be seen as a tool for the often-undemocratic leaders in the region to ward of potential competitors. In the SADC, the ASF forms an integrated part of the regional structures, and for members like South Africa it is also a means of making sure that a new DRC-type intervention does not take place again by institutionalising principles for deployment and interventions. Former South African Deputy Minister for Foreign Affairs, Pahad, argued in 2007 that the future tasks of the SADCBRIG were to handle for instance intra-state conflicts.

Such intra state conflicts and trans-national activities are generally perpetrated by sub state actors or "war lords", non-state actors, militias, criminal elements and armed civilians and not solely by regular armies. As a result social cohesion and state institutions collapse, law and order breaks down, banditry and chaos prevail and the civilian population flees the conflict region or the country. ${ }^{10}$

Pahad's view stresses South Africa's focus on the role of the SADCBRIG, and the African security architecture in general as a means to stop and deal more effectively with conflict and emergency on the continent. However, different interpretations exist within SADC as illustrated for instance by Chissano's statement that the SADCBRIG should be seen as a dissuading factor against aggression, and the split experienced in the organisation related to the crisis in Zimbabwe. These interpretations see the regional security architecture more as a collective defence mechanism than as a broader collective security institution.

One of the problems of having a security structure within the SADC structure is that it relies on states to solve problems between states, even though many of these states constitute the very problem. Member states are themselves frequently a source of instability, governed as they are by corrupt leaders, neo-patrimonial structures and various degrees of despotism. National interests are therefore often incompatible with regional interests (Van Nieuwkerk 1999:2). However, the MDP plays an important confidence-building role and could be seen as an attempt to revive the SADC and advance stipulations concerning future defence co-operation. The MDP has therefore turned out to be an important element in the creation of the SADCBRIG as part of the wider AU security architecture.

${ }^{10}$ Media briefing by Deputy Minister Aziz Pahad, Media Centre, Amphitheatre, Union Buildings, Pretoria, 15 August 2007. 


\section{The African Stand-by Force: Principles and guidelines}

The July 2002 establishment of the ASF was the culmination of a long process in which African states had expressed the ambition of creating a military capacity and thus of providing themselves with a tool to deal with and manage conflicts on the continent. Article 13 of the protocol establishing the Peace and Security Council (PSC) as one of the AU's institutions, stated that:

In order to enable the Peace and Security Council to perform its responsibilities with respect to the deployment of peace support missions and intervention pursuant to article 4(h) and (j) of the Constitutive Act, an African Stand-by Force shall be established. Such Force shall be composed of Stand-by multidisciplinary contingents, with civilian and military components in their countries of origin and be ready for rapid deployment at appropriate notice (AU 2002 Article 13-1).

It was therefore stipulated that the ASF should include standby multi-disciplinary components with civilian, police, and military component located in home countries.

Each of the AU's five economic regions, not identical with the existing subregional organisations in Africa, became responsible for setting up an extended brigade-size formation of up to 6000 military and civilian personnel, including a brigade $\mathrm{HQ}$, four infantry formations, reconnaissance capabilities, medical units, engineering capabilities and a helicopter unit. ${ }^{11}$ The first phase of the formation ran until June 2005 and was focused on the establishment of planning elements (PLANELM) for the AU and creating capacity for handling situations falling under scenarios 1 and 2 listed below and the regions had to be able to handle scenarios 3 and 4. In Phase 2 from 2005-2010, the AU and its regions are scheduled to build capacities enabling them to handle situations like the ones lined out in scenarios 5-6.

${ }^{11}$ (AU 2005b Annex A Section II 1a). The individual brigades are to consist of: a brigade (mission level), headquarters and support unit, a headquarter company and support unit, four light infantry battalions, an engineer unit, a light signals unit, reconnaissance company (wheeled), a helicopter unit with four helicopters, a military police unit, a light multi-role logistical unit, a level-II medical unit, a military observer group, a civilian support group consisting of logistical, administrative and budget components. The policy framework sets the following additional military, police and civilian stand-by list targets to be maintained centrally by the AU: $300-500$ military observers (MilObs), 240 civilian police (CivPol), and an unspecified roster of civilian experts to fill the human rights, humanitarian, governance, demobilisation, disarmament, repatriation and reconstruction structure (Cilliers and Malan, 2005). 
The AU has decided that the civilian roster of experts is not a Phase-1 priority because UN humanitarian, development and human rights elements, which do not require a mandate from the UN Security Council, could deploy in tandem with an ASF mission. The following six missions and scenarios inform the ASF structure:

- Scenario 1. AU/regional military advice to a political mission. Deployment required within 30 days of an $\mathrm{AU}$ mandate resolution;

- Scenario 2. AU/regional observer mission co-deployed with a UN Mission. Deployment required within 30 days of an AU mandate resolution;

- Scenario 3. Stand-alone AU/regional observer mission. Deployment required within 30 days of an $\mathrm{AU}$ mandate resolution;

- Scenario 4. AU/regional peacekeeping force for Chapter VI and preventive deployment missions (and peace building). Deployment required within 30 days of an AU mandate resolution;

- Scenario 5. AU peacekeeping force for complex multidimensional peacekeeping missions, including those involving low-level spoilers. ASF completed deployment required within 90 days of an AU mandate resolution, with the military component being able to deploy within 30 days; and

- Scenario 6. AU intervention, for example in genocide situations where the international community does not act promptly. Here it is envisaged that the AU would have the capability to deploy a robust military force within 14 days.

Furthermore, the roadmap plan for the ASF stipulates that in the case of genocide, the ASF-contingents must be able to deploy within two weeks' notice, and not the thirty days required for the military component of traditional Peace Support Operations (PSO) missions. This means that brigade HQ capacity and logistic support must be in place at all times, i.e. the ASF structure needs its own permanent logistical capacity in order to be able to deploy within this timeframe. It is, moreover, acknowledged that, because no major military alliance exists on the continent, individual members, in effect the regional powers, are the only states possessing this capacity (AU 2005b Annex A Section II 1a). In addition to this, the AU members have decided to establish regionally based battalion-sized rapid reaction capabilities within each of the five regions under direct AU control (AU 2009). International donors like the UK, Denmark, France and the US are all involved in supporting and training these units. 


\section{The SADC stand-by force (SADCBRIG)}

The SADC brigade shall ... serve in peace-building efforts, including post-conflict disarmament and demobilisation and humanitarian assistance to alleviate the suffering of civilian populations in conflict areas and support efforts on major natural disasters (Mwanawasa 2007).

In the preamble to the SADC MOU on the SADCBRIG it is stated that the ambition with the creation of the SADCBRIG is to "unite our efforts towards collective self-defence and security and the preservation of peace and stability" (SADC 2007). Compared to Mwanawasa's statement above, the ambitions outlined out in the MOU with the SADCBRIG seem wider. Here both collective defence and collective security are included. This of course also correlates with the 2003 MDP that stresses the collective defence nature in the military co-operation in the region. The SADC is for instance the only region that has agreed on intelligence cooperation and exchange of information, thereby widening the early warning element that is also an integral part of the African security architecture in general. In the MOU, the potential tasks of the brigade are listed in accordance with Article 13 of the AU PSC Protocol as:

- observations and monitoring missions;

- other types of peace support missions;

- intervention in a state party in respect of grave circumstances or at the request of that state party, or to restore peace and security in accordance with Article 4(h) and (j) of the Constitutive Act;

- preventive deployment in order to prevent: (i) a dispute or conflict from escalating; (ii) an on-going violent conflict from spreading to neighbouring areas or states; and (iii) the resurgence of violence after parties to a conflict have reached an agreement;

- peace-building, including post-conflict disarmament and demobilisation;

- humanitarian assistance to alleviate the suffering of civilian population in conflict areas and support; and

- any other functions as may be authorised by the SADC Summit (SADC 2007 Article 4).

In an attempt to deal effectively with the tasks listed above, the 2007 MOU stresses that the SADCBRIG is to have a military, a police and a civilian element 
included. However, as listed further below the formation of the civilian part has been delayed, something that is not unique to SADC (AU 2009).

The staffing of the multinational planning team for SADC ASF commenced in February 2005 and is already in place (Ratala 2008). The planning team has the responsibility of assisting in the day-to-day activities of the force and of monitoring deployment readiness (Lekota 2005). This is one of the areas where the force has experienced problems, which is closely related to the lack of trust and a "we feeling" between the SADC members, as argued earlier. Even though the members have pledged forces to the SADCBRIG, it has been difficult to be allowed to inspect these pledged capabilities, often due to security concerns. A general trust lacks amongst members to allow SADC officials to inspect its contingents. Another element is that the pledged forces and capabilities are often not readily available. The dedicated contingents are either being used for other tasks, and are therefore not on stand-by, or the pledged capability simply does not exist and will only be available at a later date (Ratala 2008). Despite this, there seem to be consensus between different government departments in South Africa, that the SADCBRIG will be operational by the summer of 2010, even though it was described in 2008 as a "paper tiger" (Bona 2008; Ratala 2008).

An important part of the process of operationalising the SADCBRIG is to have joint standards of training and doctrines. As mentioned above, the SADC's RPTC is located in Harare, and was initially an important institution in creating a common platform and interoperability amongst between the different forces. However, the RPTC was closed in 2002 due to the withdrawal of donor funding. ${ }^{12}$ This was a severe setback in the attempt to secure harmonisation and co-operation in peacekeeping between SADC countries. The centre lacks funding, but has nonetheless been designated to function as the SADC's regional PSO training centre. However, in 2009 an EU expert group recommended that the RPTC should be supported as the only designated regional training centre, directly controlled by the OPDSC. This is an important development, because the SADC's insistence on keeping the RPTC as its only designated centre is one of the issues that led to donor

12 The RPTC was closed in early 2002 after the Danish government withdrew its donor support as a consequence of the political crisis in Zimbabwe. This happened despite the fact that Denmark had signed a multilateral agreement with SADC, and not Zimbabwe. The matter therefore created a lot of anger amongst member states at the time. The Zimbabwe issue has since blocked Danish, and western, donor support for the RPTC. The Danish government's logic is peculiar in the sense that Denmark is considering supporting the EASTBRIG, including states like Ethiopia, Sudan, Kenya and Somalia, while still refusing to become involved in the SADC on account of Zimbabwe. 
withdrawal in 2002. It has furthermore been an issue that has created severe political tension inside SADC, due to primarily Zimbabwe's insistence on the RPTC as the region's only designated training centre of its kind. This also means that, while SADC has not been an efficient tool for South Africa so far in the area of security, the organisation now seems to be on the move at last.

\section{The structure and status of the SADCBRIG}

The AU has, through its framework document, outlined the elements to be included in the new brigade structure. However, the respective regions differ in the way they have chosen to form and shape their individual brigades. The SADC has, for instance, chosen not to form a permanent Brigade $\mathrm{HQ}$, but to set it in place only when the brigade is to be deployed. This means that the only standing permanent structure in the SADC, apart from training centres, is to be the planning element (PLANELM) established at the SADC HQ in Gaborone, Botswana in 2005 (Pahad 2007). The PLANELM is to be a tool of the OPDSC, taking its guidance from the SADC Committee of Chiefs of Defence Staff and the Committee of Police Chiefs respectively (SADC 2007, Article 6) The SADC members furthermore decided to establish a logistics base in Botswana.

The forces themselves must be on standby in their home countries, and can therefore not be designated to other tasks. In the case of a deployment, the PLANEM will not be included in the deployed force. Each member state has the responsibility of ensuring that the pledged forces are available and have reached a level of training that is comparable to the standards outlined by the RPTC on the basis on UN/AU standards (SADC 2007, Article 8). The contributing states will be reimbursed for their pledged troops and equipment. In the event that they do not comply with the operational standards, the reimbursement will be reduced. This is important because past experience from South African deployments in the DRC and Burundi shows that such designated forces often had problems meeting the operational standards required by the UN (see for instance Mandrup 2007a, Mandrup 2009). This is however, not a uniquely South African problem, and the operational standard of the SANDF must be considered much higher than that of many of its SADC partners.

Despite the mentioned shortcomings and according to the AU itself, the formation of SADCBRIG is moving forward at a steady pace. The framework seems to have been put in place leaving only the civilian component and standby roster to be finalised. (See Table below) 


\begin{tabular}{|l|c|}
\hline Framework documents & $\checkmark$ \\
\hline Memorandum of understanding & $\checkmark$ \\
\hline PLANELM & $\checkmark$ \\
\hline Brigade HQ & $\times$ \\
\hline Pledged Units & $\checkmark$ \\
\hline Civilian components & On-going \\
\hline Centres of excellence & $\checkmark$ \\
\hline Stand-by roster & On-going \\
\hline
\end{tabular}

(Source: AU 2009)

Part of the establishment of the SADCBRIG is also the accomplishment of specific benchmark criteria for testing the operational readiness level of the SADCBRIG. The brigade managed early in 2009 to conduct both its Mapping Exercise (MAPEX) and its Command Post Exercise (CPX) successfully, while in September 2009 it conducted a brigade size (8 000 soldiers) field-training exercise (FTX), named Golfinho, which included both maritime and land elements. This shows that the SADC members have moved a long way in their attempt to operationalise the SADCBRIG. However, the organisation still needs to develop its civilian component, because too much of the initial focus centred on the formation of military elements (Alghali 2009).

The primary obstacle in establishing SADCBRIG is a lack of funding (Ratala 2008). The SADC members have attempted to conduct the exercises and the establishment of the SADCBrig without significant donor support. This was done for political reasons, in an attempt to remain independent from donor involvement, but also as a consequence of the sanctions against Zimbabwe. The problem for the SADC members has been and still is that funds are needed to be able to conduct training and exercises, to support the running of the RPTC and to ensure that this centre has the capacity to function as the regional centre for PSO training, and for deployment of the SADCBRIG-designated troops. This is also an area where the 
political differences between the member states are visible, with certain members being more than others willing to accept donor funding.

\section{South Africa and the SADCBRIG}

Former South African Defence Minister Lekota promised in Parliament that the SADC ASF would be structured and ready for simple peace missions by 30 June 2005. (Lekota 2005) According to the plan listed in the scenarios above, the brigade must be fully operational by 2010 , and be able to undertake everything from simple observer missions to military interventions. South Africa has been very active in the formation of the ASF, and SADCBRIG in particular, which, according to the plan, should be able to provide the African Union (AU) by 2010 with a rapid reaction capability consisting of five regionally based brigades. The responsibility for PSOs and the creation of the ASF structures have to a large extent been placed upon the regionally dominant states, for instance South Africa in southern Africa and Nigeria in West Africa (AU 2005b Annex A Section II 1a). South Africa needs to be able to provide the equipment that other members do not possess, as reflected in the country's initial decision to acquire a long-distance transport capability. The decision by the South African government to cancel the long-distance aircraft acquisition is potentially problematic, because this capability was presented with the rationale of providing the African security architecture with a much-needed strategic airlift capability. Part of the role as a regional power is that South Africa must be willing and able to act as the lead nation in African PSOs. This was - as previously mentioned - stressed at the AU level, where the bigger nations have special tasks in the ASF (AU 2005b Annex A Section II 1a). The expectations of lead nation come both from the global and regional levels and must be seen as necessary if South Africa wants acceptance of its benign role outlined in Mbeki's statement in the introduction.

Even though the Nordic Stand-by High Readiness Brigade (SHIRBRIG) ${ }^{13}$ structure is the model on which the AU standby system is based, it is important to acknowledge that the ASF must be able to undertake a larger variety of tasks than was ever expected of the SHIRBRIG force, which, in its initial phase, was intended for peacekeeping missions only. One of the areas where the ASF will differ from the SHIRBRIG model is that the individual units will not be self-contained for sixty days and each ASF brigade will, therefore, have a standing logistical capability. Furthermore, the ASF has distanced itself from the SHIRBRIG model within the

13 SHIRBRIG was declared operational on 1 January 2000, and has so far been deployed in UN missions in for instance Ethiopia/Eritrea in 2000, and in Sudan in 2005. The brigade was closed down in June 2009. 
area of military intervention capacity. The African force will be based on the logistical and HQ capabilities of individual members, something not pursued to the same degree in the SHIRBRIG case. Thus, the ASF must be seen as a conventional military force (though not a standing one), with an offensive capability. This means that, in order to be able to fulfil its role as the regional power in SADC, South Africa must be able to provide specialised functions, especially in the areas of logistics and the HQ role.

SADC members have nonetheless pledged their contributions to SADCBRIG, and South Africa will deliver the capabilities that the other members lack. The South African National Defence Force (SANDF) has pledged a parachute battalion, engineering capability, sanitation (including a field hospital), harbour patrol boats, signal capacity, divers, naval support vessel and air transport, to fill the gaps of the other member states. However, it is important to notice that most of the pledged forces are not rotational, and that several of the pledged units only have limited operational readiness. The recent decision by the South African government to increase defence spending is a necessary move if the country wants deal effectively with the capacity problems in the SANDF.

According to the South African government's defence acquisition agency, ARMSCOR, the SANDF does have excess capacity in the area of, for instance, communications, which would enable it to provide this capability to the other members of an SADC-based ASF (ARMSCOR 2004). Furthermore, the SANDF's future is more focused on SADC and the AU, that is, on the attempt to assess and harmonise force requirements. However, this does not change the fact that the SANDF faces serious problems to maintain acceptable operational readiness levels and thus placing serious questions marks on its ability to function in the lead nation role. $^{14}$

South Africa's military capabilities and its ability to function as a lead nation in PSOs and in the SADCBRIG may seem bleak. There seem to be two aspects to this. One is the force-to-force ${ }^{15}$ ratio in future deployments, that is, how many and what quality of soldiers and equipment does South Africa need in order to fulfil its future African deployments? Conflicts in Africa are usually low-tech and low-intensity by nature. The technological level of the SANDF will exceed the forces it will encounter while deployed. It will therefore have technological advantages compared

14 See for instance the DOD Budget briefing to the Parliamentary Portfolio Committee on Defence, July 2009; DOD annual reports for the last ten years; Mandrup 2007a; Mandrup 2009.

${ }^{15}$ Force-to-force ratios measure how big an international force has to be to balance the indigenous force and enable it to fulfil its mandate. 
to most African armies or militias it will be faced with. Moreover, the SANDF is a relatively potent and disciplined force, though there is a general perception within the force of a lowered capacity and quality. The second aspect is the force-space ratio in relation to the tasks given to the SANDF. It is clear that this is potentially a problem for the SANDF due to its current limited deployment capacity. If the maximum sustainable force level that the SANDF can deploy is approximately 4000 soldiers (the level in 2009), this might well turn out to be insufficient to solve the tasks that South Africa will be expected to solve. However, the capacity to function as a lead nation is not necessarily tied to the capacity to deploy large force numbers. Of significance for South Africa is the country's ability to provide the critical functions and thus to tie the operation together. South Africa is slowly expanding its capacity in this regard and will be able to undertake such a commitment. Nigeria, by comparison, has an army of 150000 soldiers and a much larger deployment potential, but it lacks much of the critical functional capacity required. ${ }^{16}$ Due to South Africa's economic priorities and the structural problems of the SANDF itself, it seems unlikely that its capacity will exceed the current 4000 ceiling during peacetime.

It is important to realise that so far the SANDF has been able to carry out the tasks it has been allocated. It can be argued that this relatively limited armed force has shown an impressive ability to simultaneously deploy more than 4700 soldiers internationally and domestically since the summer of 2003. Deployment in international PSOs has also given the SANDF valuable mission experience, which will be extremely useful in setting up the SADCBRIG. The first phase of the strategic defence procurements for new naval and air systems will also have made its impact felt, and thanks to the initiation of a second phase of the acquisition programme in 2010, the army will be able to benefit from an increased focus regarding its equipment needs. However, the problems it has in attracting and retaining critical personnel will reduce its capacity to deliver such capabilities to the SADC ASF brigade. What is interesting to see is that the co-operation, and especially contributions in SADCBRIG, is described as joint SADC, when South Africa in reality is often the main provider. However, this is not unique to the $\mathrm{SADC}$, but can be seen in several international organisations, like for instance NATO, where bigger states often provide more capabilities, but the effort is presented as combined.

\footnotetext{
${ }^{16}$ In the African Union Mission in Sudan, South Africa was the only contingent that brought its own equipment. The other force contributors were provided with their main equipment from Western donors, either directly or indirectly from private military companies on contract to support the operation with for instance logistics, maintenance, etc.
} 


\section{Conclusion}

This article commenced by asking whether a lack of common values was blocking the creation of a security community in the SADC. There is no clear answer to this question. SADC members have introduced a number of treaties that indicate both shared values and a sense of common belonging. This shows that the intention to create a security community is there, thus making collective defence redundant. However, the organisation is split between the reformists and a group of states that only pay lip service to the principles of democratic governance and human rights, Zimbabwe being a good example. Only time will show whether the South African strategy of being a good example and expecting fellow members to implement the new common SADC values will actually work. The 2008 elections in Zimbabwe once again functioned as a litmus test for SADC members' willingness to take the democratic principles that is said to tie the organisation together seriously, or, as Vale and others argue, to show whether the organisation's very existence is tied to that of protecting the political elites in power. At the moment, the nature of SADCBRIG points in both directions, as alluded to by the SADCBRIG MOU's dual focus on collective defence and collective security.

Whether the SADCBRIG will be fully operational by 2010 is too early to say, but South Africa is doing much to make it happen. The recently conducted brigade size exercise, FTX Golfinho, showed that the SADCBRIG has moved some way in becoming operational. However, the continued instability in some SADC member states means that serious questions hang over their ability to provide the pledged units. Much depends on the larger and stronger member states to take the lead and provide the capabilities that the other states cannot. The Pretoria government's decision to cancel the acquisition of long-distance military transport planes is not good news. It could be a signal from the South African government that it increasingly focuses on domestic issues.

However, the major question is whether a lead nation will be a necessary condition for making the SADCBRIG work. The lack of trust between members results in difficulties or long-term lapses to establish the SADCBRIG. Another problem could be that it can become difficult for SADCBRIG members to agree on when, how and under which conditions the brigade should be deployed, especially if the members do not share common values. South Africa, as the regional power, therefore needs to create the required framework and sense of security for member countries, to build trust. South Africa consequently needs to be willing and able to provide this framework, and not just to be a partner. However, South Africa also needs to have a force with a readiness level that allows it to function effectively as a lead nation in the SADCBRIG. 


\section{References}

Alghali, Z.A. 2009. The civilian dimension of SADC's stand-by force. Pax Africana Newsletter, 5(2), July.

AU, 2002 Protocol relating to the establishment of the peace and security council of the African Union, Adopted by the 1st Ordinary Session of the Assembly of the African Union Durban, 9 July 2002.

AU, 2005a, AU Non-Aggression and Common Defence Pact, Adopted by the fourth ordinary session of the assembly, held in Abuja, Nigeria, 31 January

AU, 2005b, Roadmap for the operationalization of the African Standby Force, Experts' meeting on the relationship between the AU and the regional mechanisms for conflict prevention, management and resolution, Addis Ababa, 22 - 23 March 2005

AU, 2009. Briefing received in AU HQ, The African Union Peace and Security Mechanism \& The African Standby Force. By Mamadou Mbaye, Lt-Col (rtd), 2 April 2009

Baker, D-P. \& Maeresera, S. 2009. SADCBRIG intervention in SADC member states: Reasons to doubt. African Security Review, 18(1), pp.107-110.

Cawthra, G. (ed.). 2009. African Security Governance: Emerging Issues. Johannesburg: FES/CSDM.

Chissano, J. 2004. Opening speech as chairman of the AU at the Extraordinary African Union Summit in Libya, 27 February.

Cilliers, J. and Malan, M. 2005. Progress with the African Standby Force. ISS Occasional Paper 98, Pretoria, May.

Cox, R. 1981. Social forces, states and world orders: Beyond international relations theory. Millennium Journal of International Studies, 10(2), pp.126-155.

Dlamini-Zuma, N. 2003. Speech given at the meeting of Experts on a Common African Defence and Security Policy, March 2003, Johannesburg.

Dlamini-Zuma, N. 2008. Remarks upon assuming the chair of the SADC Council of Ministers, Sandton, 14 August.

DOD 2009. Budget briefing to the Parliamentary Portfolio Committee on Defence, July. 
Hammerstad, A. 2003. Defending the state or protecting the people? SADC security integration at a crossroads. SAIIA Report No. 39, November.

Holsti, K. 1996. The State, War, and the State of War. Cambridge: Cambridge University Press.

Ikenberry, J. 2004. Illusions of empire: Defining the new American order. Foreign Affairs, 83(2), March/April.

ISS 2009, Profile of SADC, Available at http://www.iss.co.za/AF/RegOrg/ unity_to_union/sadcprof.htm (accessed 30 November 2009).

Jervis, R. 1982. Security regimes. International Organization, 36(2), pp.357-378.

Jervis, R. 1985. From balance to concert: A study of international security cooperation. World Politics, 38(1), October, pp.58-79.

Lekota, M. 2005. Minister of Defence Lekota's budget speech to Parliament, 8 April 2005.

Lodge, T. 2003. Politics in South Africa. USA: Indiana University Press.

Mandrup, T. 2007a. Africa: salvation or despair: A study of post-apartheid South African government's use of the military tool in its foreign policy conduct from 1994-2006. Ph.D. dissertation. Copenhagen: University of Copenhagen.

Mandrup, T. 2009. Peace Diplomacy: The South African National Defence Force in Burundi, in G. Cawthra (ed.). African Security Governance: Emerging Issues. Johannesburg: FES/CSDM.

Mills, G. 1997. Leaning all over the place? The not-so-new South Africa's foreign policy. ISS Monograph, No. 13, May.

Mwanawasa, L. 2007, Zambian President Levy Mwanawasa launching the SADCbrig at the summit of the 14-member Southern African Development Community (SADC) in Lusaka, August 2007, available at http://www.polity.org.za/article/zambia-mwanawasa-launch-of-the-sadc-brigade17082007-2007-08-17 (accessed 03 December 2009).

Nathan, L. 2004. The absence of common values and failure of common security in Southern Africa, 1992-2003. Crisis States Programme, LSE. Working Paper No 50, July.

Nathan, L. 2006. Domestic instability and security communities. European Journal of International Relations, 2(2), pp.275-299. 
Ngoma, N. 2005. Prospects for a security community in Southern Africa - An analysis of regional security in the SADC. ISS Occasional Paper 114.

Pahad, A. 2007. Notes following media briefing by Deputy Minister Aziz Pahad, Media Centre, Amphitheatre, Union Buildings, Pretoria, 15 August.

SADC. 1992. Treaty of the Southern African Development Community. Windhoek, August.

SADC. 2001. Protocol on Politics, Defence and Security Co-operation: SADC Towards a Common Future. SADC, Blantyre, 14 August.

SADC. 2004. SADC Summit Final Communiqué, Grand Baie, Mauritius, 16-17 August.

SADC. 2007. Memorandum of understanding amongst the Southern African Development Community member states on the establishment of a Southern African Development Community stand-by brigade. Lusaka, August.

Swatuk, L. 2003. Intellectual coherency, permanent emergency: Africa in regional security studies. Paper prepared for the International Studies Association, Portland, Oregon, 25 February - 2 March.

Van Nieuwkerk, A. 1999. Implications for South Africa's foreign policy beyond the Lesotho crisis. Accord Occasional Paper, Nr. 3/99.

Thruelsen, P. (ed.). 2009. International organisations: Their role in conflict management. Copenhagen: Royal Danish Defence College.

Vale, P. 2003. Security and Politics in South Africa: The Regional Dimension. Cape Town: University of Cape Town Press.

Zuma, J. 2003. Address to the National Assembly on the occasion of Budget Vote 1, South African Parliament, 23 June, available at http://www.thepresidency.gov.za/ show.asp?type $=$ sp\&include=former_deputy/sp/2004/sp0623.htm\&ID=702 (accessed 03 December 2009).

\section{Interviews}

ARMSCOR. 2004. Briefings at ARMSCOR 15 October, Pretoria.

Bona, M. P. 2008. Interview with the Director of the National Office for Coordination of. Peace Mission (NOCPM) in the DFA, 21 February, Pretoria.

Ratala, E., 2008, Interview with Rear. Adm Head of Joint Operations Division. 21 February, Thaba Tswane.

Short, H. \& Castleman, E. 2003. Interview in the DFA. September, Pretoria. 